\title{
A STUDY ON INTRAVENOUS ODANSETRON IN CHILDREN WITH GASTROENTERITIS
}

\section{P. GUNASUNDARI ${ }^{\mathrm{a} 1}$, MURALIDHARAN SATHYAMOORTHY ${ }^{\mathrm{b}}$, CHRISTINA MARY P. PAUL ${ }^{\mathrm{c}}$, KALAI SELVI ${ }^{d}$, I. PREETHI EVANGELINE ${ }^{e}$, A. KIRAN ${ }^{f}$ AND S. KARAN KUMAR ${ }^{g}$

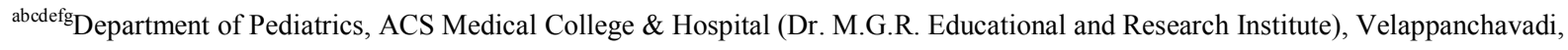
Chennai, Tamilnadu, India \begin{abstract}
intravenous rehydration in children with gastroenteritis.
Odansetron is a selective serotonin 5-HT3 receptor antagonist is well established in patients with nasuea \& vomiting associated with chemotherapy, radiotherapy and surgery. The wide distribution of 5-HT3 receptors have shown the clinical benefits in patients with gastrointestinal motility disorders like diarrhoea. Odansetron is well tolerated with lower incidence of sedation and only in isolated cases extra-pyramidal reactions molecular formula is $\mathrm{C}_{18} \mathrm{H}_{19} \mathrm{~N}_{3} \mathrm{O}$. Orally, disintegrating can be given with their food. Parentrally $0.5 \mathrm{mg} / \mathrm{kg}$ infused over 15 mins. Onset of action starts within 30 mins. Syrup odansetron $4 \mathrm{mg}$ in $5 \mathrm{ml}$. It is licensed over 1 month. More than $40 \mathrm{~kg} 0.1 \mathrm{mg} / \mathrm{kg}$ IV over 2-5 minutes. Odansetron works in the stomach to block the signals to brain that cause nausea \& vomiting. It is contraindicated in hypersensitivity patients to the drugs.
\end{abstract}

ABSTRACT

To evaluate the efficacy of odansetron for the treatment of vomiting and thus reducing the need for hospital stay and

KEYWORDS: Acute Gastroenteritis, Anti Emetics, Hospital Stay, Rehyration

\section{MATERIALS AND METHODS}

The present study was conducted in the department of paediatrics ACSMCH from April 2017 to April 2019. It is a retrospective study using antiemetics (odansetron) in acute gastroenteritis cases. Proforma was used record information on age, sex (Table 1) presenting complaints like vomiting, loose stools, fever (Table 2) duration of illness, clinical findings and administration of drugs.

\section{Inclusion Criteria}

a) Children from $1 \mathrm{yr}-12 \mathrm{yrs}$

b) Inpatients children

c) Complaints of diarrhoea and vomiting

d) Treatment with antiemetic - odansetron

\section{Exclusion Criteria}

a) Babies below $1 \mathrm{yr}$ and above $12 \mathrm{yrs}$

b) Only with diarrhoea

c) Children attending out patient block

Definition \& Main Study Variables

a) Diarrhoea: Diarrhoea is defined as the passages of atleast three watery stools in 24 hours period. However recent changes in the consistency of stools was more important than frequency.

b) Vomiting: It is an unpleasant sensation followed by nausea associated with increased salivation, enquired about projectile or not, frequency, content, bilious or not, relationship with food.

c) Oral zinc: It reduces stool volume, shortens the duration of diarrhoea, reduces severity, abdominal distension also reduces the incidence and duration of next attack of diarrhoea and thereby reduces hospital admission and stay.

d) Probiotics: It contains lactobacillus. It shortens the duration of diarrhoea with Rota virus, decreases the incidence of IV dehydration and finally reduces the number of stools. No adverse effect noted. Some countries oral dehydration solutions are fortified with probiotics and zinc.

\section{RESULTS AND DISCUSSION}

5HT3 Antagonist indicated in radiation chemotheropy post operative conditions except for adverse effects like constipation \& headaches. Drugs Availability by blocking serotonin receptors in GI Tract. Contraindicated in children less than 3 years, hypersensivity. 
Table 1: Background variables of the study subjects

\begin{tabular}{|c|c|c|}
\hline \multirow{2}{*}{ Variable } & $\begin{array}{c}\text { Classification } \\
\text { of Variable }\end{array}$ & $\begin{array}{c}\text { Number } \\
\text { (out of 100) }\end{array}$ \\
\hline \multirow{2}{*}{ Age } & $<5$ years & 35 \\
\cline { 2 - 3 } Gender & $\geq 5$ years & 65 \\
\cline { 2 - 3 } & Male & 59 \\
\hline \multirow{2}{*}{$\begin{array}{c}\text { Eating outside } \\
\text { food }\end{array}$} & Female & 41 \\
\cline { 2 - 3 } & Yes & 33 \\
\hline
\end{tabular}

Table 2: Clinical profile of the study subjects

\begin{tabular}{|c|c|c|}
\hline Parameter & $\begin{array}{c}\text { Number } \\
\text { (Percentage) }\end{array}$ & $\mathbf{9 5 \%}$ C. I \\
\hline $\begin{array}{c}\text { Diarrhea and } \\
\text { Vomiting }\end{array}$ & 73 & $64.3-81.7$ \\
\hline $\begin{array}{c}\text { Diarrhea and } \\
\text { Vomiting along } \\
\text { with fever }\end{array}$ & 27 & $18.3-35.7$ \\
\hline
\end{tabular}

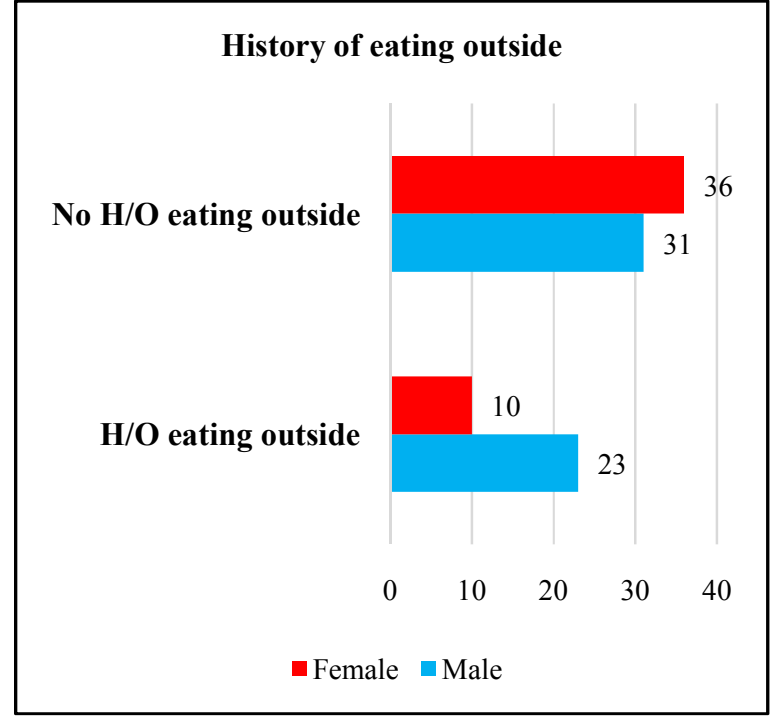

Figure 1: Graphical representation of the history of eating outside food

Table 3: Association between age of the subjects with ADD and had history of eating outside food and certain factors

\begin{tabular}{|c|c|c|c|c|c|}
\hline \multirow{2}{*}{ Variable } & $\begin{array}{c}\text { Classification of } \\
\text { variable (number of } \\
\text { people in the group } \\
\text { out of 100) }\end{array}$ & $\begin{array}{c}\text { Number of subjects } \\
\text { who had ADD and } \\
\text { had history of outside } \\
\text { food (out of 33) }\end{array}$ & $\begin{array}{c}\text { Odds ratio } \\
\text { (95\%C. I of } \\
\text { odds ratio) }\end{array}$ & $\begin{array}{c}\text { Chi - square } \\
\text { value }\end{array}$ & P - value \\
\hline \multirow{2}{*}{ Age } & $<5$ years (35) & 15 & $1.96(0.83-4.64)$ & \multirow{2}{*}{2.37} & 0.12 \\
\cline { 2 - 4 } Gender & $\geq 5$ years (65) & 18 & 1.00 & \multirow{2}{*}{2.33} & \multirow{2}{*}{0.13} \\
\cline { 2 - 4 } & Fale (59) & 23 & 1.00 & \\
\hline
\end{tabular}

\section{OBSERVATION}

From the study it is observed that diarrhoea and vomiting are common below 5 yrs, with male preponderance (Table 3), often eating food from outside while travelling is seen (Figure 1). Many times diarrhoea and vomiting alone results \& few instances it is associated with fever. Most cases were treated with probiotics and zinc.

\section{CONCLUSION}

From the study intravenus odansetron is indicated for nausea \& vomiting in children. It reduces the duration of hospital stay \& quickly inproves rehydration except for the fewer side effects like headache, constipation, fatigue $\&$ rashes.

\section{ACKNOWLEDGEMENT}

We deeply acknowledege the great help rendered by Paediatric \& NICU Department, record office staff and Ms. Preethi Evangeline. I ACSMCH for their valuable contribution. The authors would like to thank profusely Dr. Christina Mary P. Paul MD., PROF \& HOD of Community Medicine ACSMCH for her constant inspiration \& support.

\section{REFERENCES}

Khanna R., Lakshanpaul M., Burman-Roy S., 2009. Diarrhoea vomiting caused by gastroenteritis in children under 5 years: Summary of NICE guidance. BMJ, 25: 1009-12. 
Reis E.C., Goepp J.G., Katz S. and Santosham M., 1994. Barriers to use o oral rehydration therapy. Pediatrics, 93: 708-11.

Conners G.P., Barker W.H., Muslim A.I. and Goepp J.G., 2000. Oral versus intravenous: rehydration preferences of pediatric emergency medicine fellowship doctors. Pediatr Emerg Care, 16: 335 8 .

Freedman S.B., Steiner M.J. and Chan K.J., 2010. Oral ondansetron administration in emergency departments to children with gastroenteritis: an economic analysis. PLoS Med., 7: e1000350.

Domino K.B., Anderson E.A., Polissar N.L. and Posner K.L., 1999. Comparitive efficacy and safety of ondansetron, droperidol and metaclopromide for preventing postoperative nausea and vomiting: Ameta-analysis. Anesth Analg, 88: 1370-9.

Fedorowicz Z., Jagannath V.A. and Carter B., 2011. Antiemetics for reducing vomiting related acute gastroenteritis in children and adolescents' Cochrane Database Syst Rev., 9: CD005506.

Tomasik E., Ziokowska E., Koodziej M. and Szajewska H., 2016. Systematic review with mwta-analysis: Ondnsetron for vomiting in children with gastroenteritis. Ailmet Pharmacol Ther., 44: 438-46.
Freedman S.B., Powell E.C., Nava-Ocampo A.A. and Finkelstein Y., 2010. Ondansetron dosing in pediatric gastroenteritis: A prospective cohort, dose-response study. Peditr Drugs., 12: 405-10.

Roslund G., Hepps T.S. and McQuillen K.K., 2008. The role of ondansetron in children with vomiting as a result of acute gastritis/gastroenteritis who have failed oral rehydration therapy: a randomised controlled trial. Ann Emerg Med., 52: $22-9$

Cubeddu L.X., Trujillo L.M., Talmaciu I., Gonzalez V.,Guariguta J. and Seijas J., 1997. Antiemetic activity of ondansetron in acute gastroenteritis. Ailment Pharmacol Ther., 11: 185-91.

Freedman S.B., Adler M., Seshadri R. and Powell E.C., 2006. Oral ondansetron for gastroenteritis in a pediatric emergency department. N. Engl. J. Med., 354: 1698-705.

Danewa A.S., Shah D., Batra P., Bhattacharya S.K. and Gupta P., 2016. Oral ondansteron in management of dehydrating diarrhea with vomiting in children aged 3 months to 5 years: A randomised contolled Trial. J Pediatr., 169:1059. 